\title{
Rusya'da Halkla İlişkiler: Tarihsel Gelişimi ve Günümüzdeki Durumu Üzerine Doküman İncelemesi
}

DOI: 10.26466/opus.939500

\author{
* \\ Mustafa Akdağ * - Yasemin Cing1 ** \\ * Prof. Dr., Erciyes Üniversitesi, İletişim Fakültesi, Kayseri/Türkiye \\ E-Posta: makdag@erciyes.edu.tr \\ ORCID: $\quad$ 0000-0002-1818-2960 \\ ** Dr. Öğr., Erciyes Üniversitesi, Sosyal Bilimler Enstitüsü \\ E-Posta: yasminandac@gmail.com \\ ORCID: $\quad$ 0000-0002-2016-6900
}

\section{Öz}

1991 yılında SSCB'nin dağılmasının ardından Rusya Federasyonu yepyeni bir döneme başlamış, bu yeni dönem beraberinde dünyaya ayak uydurma sürecini getirmiştir. Bu anlamda halkla ilişkiler uygulamaları "Yeni Rusya"nın üzerinde özenle durması gereken bir konu olmuştur. Dağılmanın ardından başlayan halkla ilişkiler çalışmaları zamanla hız kazanmış ilk uygulamaların da kamu sektöründe olduğu görülmüştür. İlerleyen dönemlerde özel sektörde de başlayan çalışmalarla birlikte halkla ilişkiler ajansları ilk ofislerini Moskova ve St. Petersburg'da açmış ve günümüzde dünya sıralamalarına giren ajansların temelleri o dönemlerde atılmaya başlanmıştır. Bu çalışmanın amacı, SSCB'nin dağılmasının ardından halkla ilişkilerin Rusya'da kamuda ve özel sektörde nasıl uygulandığını açıklamak ve STK'ların bu konudaki durumunu ortaya koymaktır. Daha evvel yerli literatürde bu ülkenin halkla ilişkiler çalışmalarına yönelik özel bir çalışmaya rastlanmamış olması nedeniyle Rusça ve İngilizce kaynaklar üzerinden doküman incelemesi yöntemi kullanılmış ve halkla ilişkilerin gerek kamuda ve özel sektörde gerekse dernekleşme alanında oldukça aktif olarak uygulandığı ancak STK'larda ise tam manasıyla işlevlerini yerine getiremediği sonucuna ulaşılmıştır.

Anahtar Kelimeler: Rusya, Halkla İlişkiler, Rusya'da Halkla İlişkiler Faaliyetleri, Halkla İlişkiler Dernekleri, Halkla İlişkiler Ödülleri. 


\title{
Status Public Relations in Russia: Document Review on Historical Development and Current Situation
}

\begin{abstract}
After the collapse of the USSR in 1991, the Russian Federation started a brand new period, and this new period brought along the process of adapting to the world. In this sense, public relations practices have become an issue that "New Russia" should pay attention to. It has been observed that the public relations activities that started after the disintegration gained speed over time, and the first practices were in the public sector. It has been observed that the public relations activities that started after the disintegration gained speed over time, and the first practices were in the public sector. In the following periods, with the work that started in the private sector, public relations agencies opened their first offices in Moscow and St. Petersburg the foundations of the agencies in the world rankings today, started to be laid at that time. The purpose of this study is to explain how public relations were implemented in Russia in the public and private sector after the dissolution of the USSR and to reveal the situation of NGOs on this issue. Since there was no specific study on the public relations studies of this country in the domestic literature, the method of document analysis was used in Russian and English sources and public relations were very actively applied both in the public and private sector and in the field of association, but in NGOs it could not fully fulfill its functions the result has been reached.
\end{abstract}

Key Words: Russia, Public Relations, Public Relations Activities in Russia, Public Relations Associations, Public Relations Awards. 


\section{Giriş}

Kurumsal anlamda modern halkla ilişkiler faaliyetleri SSCB'nin yıkılışının ardından aktif bir şekilde uygulanmaktadır. Halkla ilişkiler, Rusya'da güçlü bir tarihsel geleneğe sahip olmasa da günümüzde iletişim alanındaki yeni uygulamalar halkın yönetim sürecinde önemli rol oynamakta ve Rusya'nın ekonomik, politik ve entelektüel gelişiminde sisteme temel katkı sağlamaktadır (Milovidova, 2015, s.2). Bazı görüşler, Rusya'da halkla ilişkilerin 1995 yılında parlamento seçimleri sırasında bilhassa siyasi yapılarda şekillenmeye başladığını ve 1996 yılındaki cumhurbaşkanlığı seçimlerinde siyasi kampanyalar için önemli bir araç olarak kullanıldığını belirtirken diğer görüşler ise 1990 yılında halkla ilişkilerin halkla temas görevi gören bir uygulama olarak öncelikle devlet dairelerinde uygulanmaya başladığı yönündedir. Aynı yıllarda Moskova'da uluslararası halkla ilişkiler ajanslarının ilk ofislerini de o tarihlerde açmaya başladığı görülmektedir (Pashentsev'den akt. Milovidova, 2015, s.3). Halkla ilişkilerin Rusya'da nispeten geç uygulanmaya başlanmasının sebebi olarak Sovyetler Birliği'nin siyasi sistemi gösterilmektedir. Otoriter sistemden dolayı iş ve ticari ilişkiler devlet tarafından yönetilmekte ve bu sebeple halkla ilişkiler çalışmaları sınırlı bir şekilde ihtiyaçları karşılayabilmektedir. Daha sonraki dönemlerde siyasi sistemde yaşanan dönüşümle birlikte iktidar ve halk arasındaki iletişimi sağlama rolü olan halkla ilişkiler propaganda amaçlı uygulanmaya başlanmıştır. 1988-1990 yılları arasında Sovyetler Birliği Komünist Partisi Merkez Komitesi Genel Sekreterliği'nde basın sekreteri kadroları oluşturulduğu, Dışişleri Bakanlığı'nda gazeteci kadrolarının da yenilendiği görülmektedir. Aynı dönemde, yasama ve yürütme organlarının basın hizmetleri de yeni bir biçime kavuşturulmuştur. Bu yapıların temel işlevleri ise; iktidardan gelen bilgilerin yayılması, devlet kitle iletişim araçlarına bilgi sağlanması, gazetecilerin akredite edilmesi ve vatandaşlardan gelen başvuruların değerlendirilmesi olarak ifade edilmektedir (Voslensky, 1991, s.19).

1990 yılının Mart ayında Sovyetler Birliği Komünist Partisi'nin yönetici rolünün kaldırılması ve 1991 yılının Aralık ayında SSCB'nin dağılmasıyla birlikte kurulan yeni devletin liderleri ülkenin ve halkın yararına olacak şekilde siyasi ve ekonomik durumlarda değişiklik 
yapmaya başlamışlardır. Bu bağlamda demokratik rejim yolunda atılan ilk adımlardan biri halka seçim hakkının verilmesidir. Kısa sürede kurulan yeni partiler, uzun süre egemen olan Komünist Partisi'ne birer alternatif teşkil etmektedir. Tüm bu gelişmeler Rusya'da modern halkla ilişkilerin şekillenmesinde önemli rol oynamıştır (Milovidova, 2015, s.4). Ülkelerin iç dinamikleri ve diş dünya ile ilişkileri ticari hayatın ve şirketlerin yapılanmalarının önünü açacağı düşünülmektedir.

$\mathrm{Bu}$ çalışma SSCB'nin dağılmasının ardından Rusya'da, devlet düzeyinde, özel şirketlerde ve STK'larda halkla ilişkiler faaliyetlerinin durumunu belirlemeyi amaçlamaktadır. Aynı zamanda çalışma kapsamında halkla ilişkiler hususunda dernekleşmenin ne düzeyde olduğu, hangi meslek örgütlerinin kurulduğu ve halkla ilişkiler adına ne tür çalışmaların yapıldığı irdelenecektir.

\section{Rusyada Genel Durum}

Rusya'da genel durum halkla ilişkilerin nasıl yapılandığını görebilmek anlamında önem taşımaktadır. Bu nedenle çalışmada, Rusya özelinde ekonomik açıdan, sosyal ve kültürel açıdan, siyasal açıdan, sağlık ve turizm açısından genel bir değerlendirme yapılarak mevcut durum ortaya konulmaktadır. Halkla ilişkilerin ortaya çıkması ve gelişebilmesi için uygun ortamın olup olmadığı bu bağlamda irdelenmektedir.

Ekonomik Durum: Rusya'da iş dünyası devletten ayrı düşünülmemektedir ve birçok sanayi dalı devletin tekelinde bulunmaktadır. Özel şirketlerin yönetim kurullarında hükümet yetkilisi üyeler yer almaktadır. Bu sebeple "The Heritage Foundation" ve "Wall Street Journal" gazetesinin, 2014 yılı Ekonomik Özgürlük İndeksi'nde Rusya 140. sırada yer almaktadır. Mevcut duruma bakıldığında Rusya'da iş kurmanın son derece zor olduğu görülmektedir, bu zorluğun sebebi olarak da zorlu mevzuatların tamamlanması süreci gösterilmektedir. Bu durum Rusya'da küçük işletmelerin açılması ve yönetilmesinden kaçınmaya sebep olmaktadır. Sistem, büyük ve hükümetle kuvvetli bağlantıları olan büyük şirketlerden yana tutum sergilemektedir. Rus oligarklara ait olan bu şirketler SSCB'nin dağılmasının ardından loans-for-shares adıyla bilinen hisse kredisi 
yöntemiyle, hükümetin plansız özelleştirme planlarıyla veya özelleştirme dışında bırakılan şirketlerin kredi karşıllı̆ında özel bankalarca işletilmesi yoluyla servet edinmişlerdir. 2000 yılında Vladimir Putin'in devlet başkanı seçilmesiyle birlikte sayılan yöntemlerle servet edinen oligarklara yönelik yaptırımlar uygulanmaya başlanmış ve bu yaptırımlar arasında vergilerini tam olarak ödemeleri ve siyasetten uzak durmaları yer almıştır. Devletin onların ticari faaliyetlerini durdurma ve işlerini tamamen ellerinden alma hakkı bulunmaktadır. 2013 yılında yürürlüğe giren yeni bir kanunla; siyasetçilerin, eşlerinin ve 18 yaşından küçük olan çocuklarının denizaşırı ülkelerde bulunan bankalarda hesap açma veya farklı finansman kaynakları edinmeleri yasaklanmıştır. Bu kanun bazı oligarkların görevlerinden istifa etmelerine bazılarının ise yurt dışında kayıtlı olan varlıklarını hayır kurumlarının inisiyatifine bırakmalarına neden olmuştur (Thoburn, 2015, s.59). Putin'in güçlü müdahalelerinin ardından Rus ekonomisi, GSYİH'ye göre dünya sıralamasında 9., satın alma gücü paritesine göre ise dünya ekonomisinde 6. sirada yer almaktadır. En büyük gelir kaynağının petrol ve doğalgaz olduğu bilinmektedir. Enerji, Rusya'nın en önemli sanayi dalını oluşturmakla birlikte hidrokarbon satışı bütçe gelirinin $\% 52$ 'sine denk gelmektedir. Enerji ürünlerinin toplam ihracattaki payı \%70'tir. Rusya, doğal gaz üretiminde dünyada 2., petrol üretiminde ise 3. sırada yer almaktadır (https://www.rgs.org, 2021). Gazprom, Rosneft ve Lukoil ülkenin önemli gaz ve petrol şirketlerini oluşturmaktadır.

Kültürel ve Sosyal Durum: Sinırların açılmasıyla birlikte birçok Rus sanatçı aktif olarak dünya sanat hayatına dahil olma fırsatı yakalamıştır. L. Kazarnovskaya, D. Hvorostovskiy ve V. Spivakov'un yönetimindeki Moskova Virtüözleri dünyanın büyük sahnelerinde ülkelerini temsil etme fırsatı bulmuştur. Rus yönetmenler de batı sinemasında kendilerine yer bularak N.Mihailkov'un Güneş Yanığı filmi 1994 yılında Amerikan Sinema Akademisinin Oscar Ödülü'ne layık görülmüştür. 90'lı yılların ardından halk eğitim sisteminde reformlar yapılmış, aktif eğitim sistemi güçlendirilerek özel yüksek eğitim kurumları yapılandırılarak daha kapsamlı hale getirilmiştir. Fakat yerli bilim adamlarının çalışmaları 1990'lı yıllarda sıkıntılı süreçlerden geçmiş 1997 yılına kadarki dönemde 
ise devletin bilim için yaptığ 1 harcamalarda kısıtlamaya gidilmiştir. Bu durum birçok uzmanın yurtdışına göç etmesine sebebiyet vermiştir. Ancak bu koşullarda dahi Rus bilim adamları bilim ve kültür alanında çok sayıda federal program geliştirmiştir. Rus kültürünün zengin mirası edebiyat, müzik, felsefe, görsel sanatlar, sinema ve mimari alanında günümüzde de etkisini göstermektedir (https://www.oecd-ilibrary.org, 2021).

Siyasi Durum: Rusya'da siyasi sistem 1993 tarihli Rus Anayasası ile belirlenmiş ve mevcut anayasa 3 bölümden oluşmuştur. Yasama, Yürütme ve Yargıdan oluşan bu bölümler birbiriyle bağlantılıdır fakat Vladimir Putin'in iktidarda olduğu dönemde yasama ve yürütmenin etkisinin daha az devlet başkanlığının ise daha güçlü bir konuma geldiği görülmektedir. Rusya Anayasası'na göre başkan devletin başkanı, başbakan ise hükümetin başı konumundadır. Çift meclisli olan Federal Meclis'i 450 üye ile Devlet Duması, 166 üye ile de Federasyon Konseyi oluşturmaktadır. Yasamanın ülke adına kararlar alma, savaş ilan etme, yasa yapma ve onaylama, antlaşmalar yapma ve onaylama ve devlet başkanını görevden alma yetkisi bulunmaktadır. Devlet başkanı yürütmenin başı ve silahlı kuvvetlerin başkomutanı konumundadır. Yürütmenin meclis kanunlarını veto etme, bakanları ve diğer memurları atama yetkisi bulunmaktadır. Anayasa Mahkemesi, Yüksek Mahkeme, Yüksek Tahkim Mahkemesi ve ilk derece federal mahkemeler yargiyı oluşturmaktadır. Hakimler, Federasyon Konseyi tarafından atanmaktadır. Konseyin, yasaları yorumlama ve anayasaya uymayan yasaları yürürlükten kaldırma hakkı bulunmaktadır (Thoburn, 2015, s.11). Rusya'da devlet başkanı 6 yıl süre ile seçilmekte, başkanlık için 35 yaşın altında olmama ve kesintisiz en az 10 yıl Rusya'da ikamet ediyor olma şartı aranmaktadır.

Eğitim: SSCB'nin dağılmasının ardından Rusya'da zorunlu eğitim 11 yıl olarak belirlenmiştir. Devletin ortaöğretim okullarında eğitim ücretsizdir fakat üniversite düzeyinde hem paralı hem parasız eğitim verilmektedir. Devlet, eğitime \%13'lük bir bütçe ayırmaktadır. Rusya'da 25-64 yaş aralığındaki bireylerin \%94'ü en az lise ve dengi okul mezuniyetine sahiptir. Bununla birlikte OECD ortalaması \%75, G20 ülkeleri arasındaki 
ortalaması da \%60 olarak kaydedilmiştir. Geçmişte eğitime yapılan yatırımlar bugünkü rakamlara ulaşılmasında rol oynadığı düşünülmektedir (https://www.oecd-ilibrary.org, 2021). Eğitimde bilim ve teknolojiye büyük önem verilmekte, bunun neticesinde bilhassa tıp, matematik, bilim ve uzay araştırmaları bölüm tercihlerinde üst sıralarda yer almaktadır. Lomonosov Moskova Devlet Üniversitesi, St. Petersburg Üniversitesi, Moskova Uluslararası İlişkiler Devlet Enstitüsü ve Ekonomi Yüksek Okulu, Rusya'nın önde gelen büyük üniversiteleri arasında yer almaktadır (Thoburn, 2015, s.77).

Sağlık: Rusya'da sağlik hizmetleri tüm ülke vatandaşları için ücretsiz olarak sunulmakta fakat uygulamada zorunlu kayıt nedeniyle sinırlı olabilmektedir. Rusya'da kişi başına alınan sağlık hizmeti oranı diğer ülkelere göre daha yüksektir. Bu durumda ülkede doktor sayısının yüksek olmasının payı büyüktür. Rusya'da bilhassa erkeklerde ölüm oranı ülke ortalamasının üzerindedir bunun sebebi olarak, alkol zehirlenmesi, aşırı sigara tüketimi, trafik kazaları ve şiddet suçları gösterilmektedir (http://ru.wikipedia.org, 2021).

Turizm: Turizm, Rusya tarihi incelendiğinde öncelik arzeden konular arasında yer almamıştır. İlerleyen dönemlerde hükümetin turizm sektörünü destekleme konusunda bazı adımları söz konusu olmuştur. 1995 tarihli Turizm için Başkanlık Karanamesi, 2011-2018 yılları arası Rusya Federasyonu İç ve Diş Turizmin Geliştirilmesi Hedef Programı, 2012-2018 yılları arası Rusya'nın Federal Hedefli Kültür Programları ve 2013-2020 yılları arası Rusya Federasyonu Kültür ve Turizmi Geliştirme Devlet Programı bu adımlara örnek gösterilebilmektedir. Söz konusu çalışmalar Rusya'nın uluslararası bir destinasyon olarak rekabet gücünün artırılmasına yönelik hedefler olarak anılmaktadır. Fakat yabancılar, Rusya'yı genellikle iş sebebiyle ziyaret etmektedir. Sektördeki işletme standartlarının yetersizliği, ingilizce dil bilgisinin yaygın olmaması ve Rus misafirperverliğinin zayıf kalması Rusya'nın turistler açısından tercih edilmemesine sebebiyet vermektedir. Bu durumda turistler Rusya'yı seyahat amaciyla tercih etmeseler de Rus vatandaşları turist olarak Türkiye ve Mısır'ı yoğunlukla tercih etmektedir. Bu durumun gelişmesindeki temel sebep de bu ülkelerin 
ikliminin yanı sıra Türkiye ve Mısır gibi ülkeler tarafından sunulan tatil paketlerinin cazip fiyatlarla sunulmasıdır (Sheresheva ve Kopiski, 2016, s 264).

\section{İlgili Çalışmalar}

Alana yönelik araştırmalar incelendiğinde hem lisansüstü tezlerde hem de makalelerde Rusya'da halkla ilişkilerin durumunu ortaya koymaya çalışan çalışmaların dünyanın çeşitli ülkelerinde bulunan akademisyenler ve öğrenciler tarafından yapıldığı görülmektedir. Yapılan çalışmaların bazılarında "Yeni Rusya" kavramı dikkat çekicidir. Sovyetler Birliği'nin dağılmasının ardından yepyeni bir oluşum sürecine giren Rusya'da halkla ilişkiler de önemli bir yere sahip olmuştur. Pyhs, ajans sahipleriyle derinlemesine mülakat yöntemiyle yaptığ 1 çalışmasında, halkla ilişkilerin batı kaynaklı olmasından dolayı adaptasyon sorunu yaşandiğ 1 fakat Rusların bu duruma ayak uydurabildikleri, yabancı ajanslarla iletişim halinde oldukları ve halkla ilişkilerin öneminin günden güne arttığı sonucuna ulaşmıştır. Ulaşılan bir diğer sonuç ise, dişarıya tamamen kapalı olan Sovyet Rusya'nın ardından "Yeni Rusya" nın Soğuk Savaş'ın baş aktörü olan Amerika ile ajanslar konusunda ortak çalı̧̧malar yürütmekte olduğudur, özellikle özel şirketler düzeyinde destek alınan ajanslar arasında yabancı ajans işbirlikleri de bulunmaktadır (2009, s.57-69). Bykov ve arkadaşlarının 2016 yılında yaptıkları bir çalışmada devlet düzeyinde halkla ilişkiler konusu araştırılmış, halkla ilişkilerin yanısıra kamu yönetimi ve hukuk alanında da bilgi gereksinimine ve birikimine ihtiyaç duyulduğu vurgulanmıştır. Ayrıca halkla ilişkişlerin St. Petersburg ve Moskova'da kamu sektöründe geliştiğini fakat bölgesel anlamda henüz aynı gelişmenin sağlanamadığı bu durumun da çağdaş halkla ilişkiler eğilimlerinin benimsenmemesinden kaynaklandığı sonucu üzerinde durulmuştur (2016, s.141). Tsetsura da Rusya'da Halkla İlişkilerin Gelişimi başlıklı çalışmasında benzer durumları vurgulayarak, halkla ilişkiler araştırmalarında bölgesel farklılıklar olduğuna bu yüzden bütüncül bir bakış açısının tam anlamıyla sağlanamadığına değinmiştir. $\mathrm{Bu}$ durumun sebebi olarak da Rusya'nın dünyanın en büyük ülkelerinden biri olmasından kaynaklanan coğrafi, politik, ekonomik ve 
kültürel çeşitliliği gösterilmiştir. Bu çeşitlilik farklı uygulamaları beraberinde getirmektedir. Ancak söz konusu olumsuz durumlara rağmen, Rus halkla ilişkiler araştırmacılarının teoride ve uygulamada, alanın gelişmesine yönelik güncel katkılar sağladıkları ve alanın büyümesi için profesyonel desteklerin verildiği çalışmada sıkça yer almıştır (2003, s.301-315).

Bölgesel uygulama farklılıklarına ve bazı aksaklıklara rağmen Rusya'da halkla ilişkiler çalışmalarına genel olarak bakıldığında özellikle uluslararası alanda varlık göstermeye yönelik çalışmalar göze çarpmaktadır. Uluslararası Halkla İlişkiler Derneğince (IPRA) düzenlenen ve "Halkla İlişkilerin Oscarları" kabul edilen "Altın Küre Mükemmellik Ödülleri" yarışmasında Rusya, 2020 yılında yirminin üzerinde ödüle layık görülmüştür. Bu durum ülkede halkla ilişkilere verilen önemin bir göstergesi olarak kabul edilmektedir.

\section{Yöntem}

$\mathrm{Bu}$ çalışmada doküman incelemesi yöntemi kullanılmıştır. Doküman incelemesi, tek başına bir araştırma yöntemi olarak kabul edilmekte, araştırılması amaçlanan olgu veya olgular ile ilgili bilgiler içeren materyallerin analizini kapsamaktadır (Yıldırım ve Şimşek, H., 2005, s.187). Geray'a (2006) göre dokümanlar; niteliklerine göre ve bulundukları ortama göre sinıflandırılmaktadır. Kitaplar, ansiklopediler, dergiler, raporlar, sözlükler ve günlükleri kapsayan materyaller Yazı Temelli Olanları; fotoğraflar, afişler ve haritalardan oluşanlar Görüntü Temelli Olanları; ses kayıtları, müzik yayınları, radyo yayınları Ses Temelli Olanları; televizyon programları, videolar, sinema filmleri gibi dokümanlar Görsel-İşitsel Temelli olanları oluşturmaktadır. Tüm bu sayılanlar niteliklerine göre dokümanlar olarak nitelendirilmektedir. Bu çalışmada yazı temelli doküman incelemesi yürütülmüştür.

Bu kapsamda, Rusya'da halkla ilişkiler faaliyetlerini konu alan tezlere, makalelere, kitaplara ve internet sitelerine ulaşılarak dokümanlar toplanmış, incelenmiş ve değerlendirilmesi yapılmıştır. Dokümanların, veri kaybına uğramadan orijinal bir şekilde çevirisi yapılmış ve metne sadık kalınarak aktarılma işlemine geçilmiştir. Ulaşılan dokümanlar belli bir sınıflama kullanılarak kronolojik şekilde tasnif edilmiştir. Bu 
sinıflama bağlamında mevcut durumun ortaya çıkarılması ve bu alanda çalışma yapacaklara kaynak oluşturulması hedeflenmiştir. Bu anlamda kullanılan tasnifleme ve doküman değerlendirilmesi ile, örgütsel yapılanma dikkate alınarak kamu kurumlarında, özel sektörde, meslek kuruluşlarında ve sivil toplum kuruluşlarında Rusya' da halkla ilişkilerin nasıl yapılandığı ortaya konulmaya çalışılmıştır.

\section{Araştırmanın Amacı ve Önemi}

Çalışma kapsamında Rusya özelinde devlet düzeyinde, özel şirketlerde ve STK'larda halkla ilişkiler yapılanmalarının durumunu ortaya koymak amaçlanmaktadır. Aynı zamanda çalışma kapsamında halkla ilişkiler hususunda dernekleşmenin ne düzeyde olduğu, hangi meslek örgütlerinin kurulduğu incelenmiştir. Ayrıca eğitim konusunun çok kapsamlı olması dolayısıyla bu çalışmada yer verilmeyecektir. Literatür incelendiğinde daha önce bu ülkenin halkla ilişkiler uygulamalarını ortaya koymaya yönelik kapsamlı bir çalışmaya rastlanamamış olması ve alandaki eksikliği dolduracağının düşünülmesi konunun önemini vurgulamaktadır.

\section{Araştırmanın Sınırlılıkları}

Araştırmanın yabancı kaynaklar aracılığı ile yürütülmesinin yanı sıra yalnızca halkla ilişkiler uygulamalarına yönelik tez, makale ve mevcut internet sitelerinden ulaşılan bilgilere dayanması çalışmanın sınırlılığını oluşturmaktadır.

\section{Rusya' da Halkla İlişkiler}

Halkla ilişkiler tarihinin insanlık tarihi kadar eski olduğu söylenebildiği gibi kurumsal yapıların oturduğu bir döneme kadar halkla ilişkilerin temellendiği söylenebilir. Geçmişte halkla ilişkiler olarak adlandırılmamalarına rağmen kamuoyunu bilgilendirme, olumlu imaj oluşturma ve etkili iletişim kurulması hususları halkla ilişkiler anlamında ele alınabilecek uygulamaların tarihini daha da önceleyebilecektir (Akdağ ve Erdem, 2009, s.3). Dönemsel olarak 
bakıldığında ise Rusya'da modern halkla ilişkilerin gelişmesini 3 dönem olarak ele alabilmek (Milovidova, 2015, s.5) mümkündür:

İlk Dönem (1988-1991); bu dönem kurumsallı̆̆ın doğuşu olarak adlandırılmaktadır. Devlet yapılarındaki hizmetlerin genişlemesi, Moskova'da uluslararası ajansların ofislerinin açılması, girişimciliğin gelişmesi, temel düzeyde hizmet sunan yerli halkla ilişkiler şirketlerinin ortaya çıkması bu dönemde yaşanmıştır.

İkinci Dönem (1991-1995); büyüme ve oluşum aşaması olarak adlandırılan bu dönemde Rus halkla ilişkiler ajansları yabancılardan edindikleri deneyim ve bilgi birikimlerini adım adım yerel koşullara uyarlamaya başlamışlar, giderek daha büyük halkla ilişkiler etkinlikleri ve bilgilendirme kampanyaları düzenlemişlerdir. Bazı üniversitelerde Halkla İlişkiler bölümü açılmış ve halkla ilişkiler için özel şirketler birliği olan Rusya Halkla İlişkiler Derneği kurulmuştur.

Üçüncü Dönem (1996-1999); bu dönem Rusya'da halkla ilişkilerin gelişiminde atılım dönemi olarak adlandırılmaktadır. Bu yeni dönem hedef kitlelerle daha hassas ilişkilerin kurulmasını gerektirmiştir, çünkü halk iktidardaki siyasi parti tarafından otoriter bir şekilde kontrol edilemediğinden halk ile iktidar arasındaki iletişim kaynağı olarak halkla ilişkiler çok daha önemli bir konuma gelmiştir. Hükümetlerin isteklerini basitçe empoze edemeyecekleri anlaşılmış ve halkı dinlemek, anlamak ve bilhassa seçmenin konuştuğu dili konuşmak durumunda kalmışlardır.

Rusya'da halkla ilişkiler alanında çalışan akademisyenler halkla ilişkiler kavramına bölgesel yaklaşmaktadır bu yüzden halkla ilişkilerin Rusya'da net bir teorik tanımı yapılamamaktadır. Argümanlar bir bölge veya şehir üzerine yapılan araştırmalara göre şekillenmektedir. Örneğin Clarke, konuya Moskova'daki halkla ilişkiler özelinde yaklaşırken Guth, St. Petersburg'a göre yaklaşmaktadır. Bu yüzden Rus halkla ilişkiler uygulamalarının tümüne bütünsel olarak bakabilmek pek mümkün olmamaktadır. Bölgesellik durumuna ek olarak çağdaş hakla ilişkilerin üniversitelerde ders olarak okutulmasında da sektöre odaklılık göze çarpmaktadır. Müfredat, fakültenin uzmanlığına bağlı olarak farklılık 
göstermektedir, örneğin; halkla ilişkiler St.Petersburg, Voronezh ve Ural Devlet Üniversitesi'nde gazetecilik odaklı iken, Moskova Devlet Yönetim Akademisi, St.Petersburg Elektro-Teknik Üniversitesi ve Voronezh Devlet Teknik Üniversitesi'nde iş ve pazarlama odaklıdır. Fakat genel olarak bakıldığında Rus akademisyenler tarafından yayınlanan halkla ilişkiler ders kitaplarının ve vaka çalışmalarının en popüler olanları çoğunlukla politik halkla ilişkilerin doğasını anlamaya, bu alandaki uygulamaları analiz etmeye, siyasi kampanyaların nasıl organize edileceğine ve seçim kampanyalarında halkla ilişkiler tekniklerinin nasıl kullanılacağına dair pratik tavsiyeler içeren siyasi halkla ilişkiler üzerinedir (Tsetsura, 2003, s.303-304).

Rus bilim insanları Rusya'da halkla ilişkileri incelerken uygulamalar hakkında teori oluşturmaktan ziyade uygulamaların işlevsel tanımına odaklanmaktadır. Halkla ilişkilerin Rusya'da tarihsel gelişimine bakıldığında gerek kamuda ve özel sektörde gerekse dernekleşme yönünde önemli adımlar atıldığı görülmektedir.

\section{Kamu Sektöründe Halkla İlişkiler}

Rusya'da teknolojinin farklı kullanımlarıyla birlikte gelişmeye devam eden halkla ilişkiler 10 yıllık dönemde kamu alanında en hızlı gelişen alanlardan biri haline gelmektedir. Örneğin federal düzeyde Rusya parlamentosu tam zamanlı halkla ilişkiler çalışanı sayısını giderek artırmakta (Chumikov ve Bocharov, 2013, s.110), yerel düzeyde de halkla ilişkiler uzmanları bölge mahkemelerinde, polis ofislerinde, yerel yönetim organlarında ve devlet tıp merkezlerinde görev almaktadır. Bu eğilim, Devlet Enstitülerinde Halkla İlişkiler Dergisi'nin kurulmasında ve yeni ders kitaplarının yayınlanmasında kendini göstermektedir (Markov, 2014, s.12). 2015 yılında yapılan bir araştırmada, devlet düzeyinde halkla ilişkilerin en yaygın kullanıldığı alanlar incelenmiş ve en üst sırada medya ilişkileri, ardından web sayfası, gazeteler ve resmi bültenleri kapsayan medya kanalları aracılığı ile bilgi verme, üçüncü sırada ise halkı bilgilendirme yer aldığı sonucuna ulaşılmıştır (Bykov vd., 2016, s.137).

Rusya hükümeti halkla ilişkiler hizmetleri konusunda yabanc1 şirketlerden de destek almaktadır. Bunun bir örneği olarak 2007-2014 
yılları arasında Başkan Vladimir Putin'in izni doğrultusunda Rusya'nın uluslararası imajını destekleyecek hizmetler almak adına Amerikan iletişim şirketi Ketchum'dan destek alınmasına karar verilmiş ve şirkete yaklaşık 2 milyon dolar ödeme yapılmıştır (https://www.nytimes.com, 2020).

Rusya devlet kurumlarınin resmi sosyal medya hesapları incelendiğinde gerek kurumların kendisinde gerekse bağlı kurumlarda sosyal medya uygulamalarından aktif şekilde faydalandıkları görülmektedir. Bakanlık düzeyinde neredeyse tüm kurumların bilgi edinme ve iletişim bölümleri bulunmaktadır. Örneğin Ekonomi Bakanlığı, İçişleri Bakanlığı resmi Twitter hesabından güncel paylaşımlar yaparak halkı bilgilendirmektedir. Ayrıca Rusya Devlet Başkanlığı'nın web sitesinde vatandaşlara Cumhurbaşkanına itiraz etme olanağı, başkana mektup gönderme, vatandaşların Rusya Federasyonu Cumhurbaşkanı Resepsiyonu'nda kabulü için kişisel randevu oluşturma ve şikayet bölümleri yer almaktadır. Bunlara ek olarak 2020 yılının Aralık ayında Vladimir Putin ülke gündeminin, güncel sorunların ve çözüm önerilerinin paylaşıldığı Yıllık Basın Toplantısı düzenlemiş ve burada halkla buluşmuştur. Birçok televizyon kanalı ve radyodan canlı olarak yayınlanan programa halkın katılmasına imkan tanınarak basın toplantis1 sirasında "https://moskva-putinu.ru" web sitesinden veya "Moskova-Putin" mobil uygulaması aracılığıyla vatandaşlardan gelen sorular yanıtlanmıştır. (http://kremlin.ru, 2020). Verilen bilgilere bakıldığında iki yönlü bir iletişimin kurulmaya çalışıldığ fakat sonuçlarına dair bilgilere ulaşılamamaktadır. Bunlara ek olarak Rusya Federasyonu'nda birçok bakanlık halkla ilişkiler ajanslarından destek almaktadır. Örneğin ülkenin önemli ajanslarından AGT İletişim Ajansı, Rusya Federasyonu Eğitim Bakanlığı'na 2006 yılından itibaren, Eğitimin Geliştirilmesi için Federal Hedef Programı'na kapsamlı bilgi desteği sağlamaktadır. Bu süre zarfında, bir iletişim stratejisi geliştirilmiş, medya ile çalışma oluşturularak okul öncesi, genel ve ek eğitim alanında Yol Haritası eylem planına bilgi desteği, organizasyon gibi bir dizi proje uygulanmıştır. 1990 yılında ilk defa "Tüm Rusya-Yııın Öğretmeni" yarışması düzenlenmeye başlamıştır. Çeşitli konularda projeleri olan öğretmenlerin yer aldığı takımlardan oluşan yarışmanın amacı, birlikte çalışmayı bilen, yaptığı çalışmalarda modern 
uygulamaları hayata geçirmeye hazır olan öğretmen ekiplerini desteklemek ve onları bu konuda teşvik etmektir (https://teacher-ofrussia.ru/, 2021). Diğer bir örnek ise Rusya Federasyonu Federal Tibbi ve Biyoloji Ajansı'dır. 2009 ve 2010 yıllarında, Rusya'nın 54 bölgesinde ücretsiz kan bağışını teşvik etmek için bir proje düzenlenmiştir. Proje, bölgesel kan merkezlerinin markalaşmasını, STK'ların, hükümet yetkililerinin ve uzmanların katılımıyla etkinlikler düzenlemeyi, öğrenci bağış hareketini teşvik etmeye yönelik programların uygulanmasını, öğrenciler için bilgilendirme projelerini, bir reklam kampanyasının geliştirilmesini ve uygulanmasını, promosyon ürünlerinin üretim ve lojistiğinin sağlanmasını kapsamaktadır (https://fmba.gov.ru/, 2021). Rusya Federasyonu Sanayi ve Ticaret Bakanlı̆̆ı, tekstil endüstrisinin ürünlerinin tanıtılması için faaliyetlerine eşlik eden bir dizi iletişim ve reklam kampanyasının geliştirilmesi ve uygulanması adına ajanslardan destek almakta, kereste ve kimya endüstrisini dış pazarda tanıtmayı amaçlamaktadır.

Verilen örnekler Rusya'da halkla ilişkiler faaliyetlerinin kamu sektöründe gelişim sürecinde olduğunu bu anlamda büyük önem taşıdığını ve profesyonel ajansların desteğine ihtiyaç duyulduğunu göstermektedir.

\section{Özel Sektörde Halkla İlişkiler}

Rusya ve Türkiye arasında yürütülen bilhassa turizm tanıtım faaliyetlerinde Rus reklam ajansları aktif rol oynamaktadır. Firmaların özellikle yurt dışındaki tanıtımlarında reklamların rolünün büyük olduğu anlaşılmaktadır. Billboardlardan, araç giydirmeye, televizyon, dergi ve gazete reklamlarına kadar medya satın alımları sıklıkla görülmektedir. İşbirliği yapılan turizm operatörleri reklam ajanslarıyla çalışmakta ve bu sayede havayolu şirketleri ve tren dergilerine reklam verilmektedir. Ajanslara ait araçların tanıtımı yapılan bölgenin karakteristik turizm sembolüyle giydirilmesi de Rusya'da ajansların sıkça tercih ettiği tanıtım yollarındandır. Turizmin yanısıra ticarette de reklam ajansları aktif rol oynamakta, düzenlenen uluslararası fuarlarda yabancı firma adına Rusya'nın ünlü sosyal medya fenomenlerinin standlarda misafir edilmesi yeni uygulanmaya başlayan faaliyetler 
olarak göze çarpmaktadır. Aynı uygulama Rus fenomenlerin ülkemizin tanıtımını kendi ülkelerinde yapmaları için de kullanılmaktadır, bu yeni uygulamayla artık reklam ajansları sosyal medya fenomenleri ile ortak çalışmalara başlamıştır. Böylelikle uluslararası tanıtımlarda geleneksel yöntemlerin yanısıra yeni eğilimler denenmeye başlanmıştır. Ayrıca son yıllarda Rus halkla ilişkiler ve reklam ajansları gerek düzenlenen yarışmalar gerekse tanıtım çalışmalarıyla dünya çapında da etkili rol oynamaya başlamıştır (Cıngı, 2019, s.75).

Dünyada halkla ilişkiler endüstrisinde en yetkili bağımsız kaynaklardan olan The Holmes Report'un iletişim şirketlerinin küresel çapta en iyi 250 halkla ilişkiler ajansını belirlediği “Top 250 Global Rankings 2020" verilerine göre; Mikhailov \& Partners 111. sırada, Cros 166.sırada, EM ise 221. sırada yer almıştır. Daha evvelki yıllarda AGT İletişim Grubu, iMARS Grubu ve Pro-Vision Grubu da siralamada yer bulmuştur (https://www.PRovokemedia.com/, 2021) ${ }^{1}$. Önde gelen halkla ilişkiler şirketlerinin yanısıra Rusya' da önemli medya aktörlerinden olan GazProm Medya, Rusya'nın en büyük medya holdingi olma sıfatını taşımaktadır. Holdingin sahibi ise devlete ait GazProm şirketidir, kuruluş aynı zamanda NTN ve NTV-PLUS kanalları ile birlikte Eko Moskova ve Komedi Radyo istasyonlarının da kontrolünü sağlamaktadır (Thoburn, 2015, 85).

Rusya günümüzde azımsanamayacak sayıda halkla ilişkiler ajansına sahiptir. Söz konusu ajanslar dünya çapındaki büyük şirketlere de danışmanlık hizmeti sunmaktadır (https://www.alladvertising.ru, 2021). Teknolojinin gelişmesi, internetin daha geniş kitleler tarafından kullanılması ve sosyal medyanın çağımızda tanıtım faaliyetlerinde etkin bir şekilde kullanılması Rusya'nın da bu alanda aktif olmasını gerektirmiştir. Ajans sayılarının artması ve nitelikli içeriklere sahip olması ülkede özel sektörde halkla ilişkilere verilen önemin göstergesi olarak görülmektedir. Sözkonusu ajansların detaylı bir şekilde incelenmesi özel sektörün ulaştığı yeri göstermesi açısından anlamlıdır.

iMARS: iMARS 2001 yılında Rusya'da kurulmuştur ve kuruluşundan bugüne Rus iletişim şirketleri arasında önemli bir konumda yer

\footnotetext{
${ }^{1}$ The Holmes Report, 2021 yılından itibaren "PRovoke Media" adıyla anılmaya başlanmıştır.
} 
almaktadır. Kendisini Rus iletişim pazarının kilit oyuncularından olarak nitelendiren kuruluşun müşterileri arasında; X5 Perakende Grubu, MediaMarkt, MasterCard, Rosneft Petrol Şirketi, Rosatom Devlet Şirketi, Rus Demiryolları, Moskova Metrosu yer almaktadır. Ayrıca kuruluş, AKOS, AKAR ve RASO üyesidir (http://imars.ru/, 2021).

MIKHAILOVEPARTNERS: Mikhailov\&Partners The Holmes Report'a göre dünyanın en büyük 100 iletişim şirketi arasında yer almaktadır. Otomotiv endüstrisi, bankalar ve finans kuruluşları, madencilik ve metalurji, devlet kurum ve şirketleri, alt yapı ve ulaşım, medya, yiyecek ve içecek, spor, ilaç ve sağlık gibi 20'nin üzerinde sektörü kapsayan hizmet alanı ile hedef kitlelerine medya ve halkla ilişkiler alanında destek sağlamaktadır. Moskova ve St.Petersburg'da iki şubesi bulunmaktadır. Ayrica sosyal sorumluluk alaninda etkin rol oynamaktadir (https://m-p.ru/, 2021).

CROS: 1995 yılında Rusya'da kurulan Cros, dünyanın önde gelen iletişim ajanslarındandır. 2019 yılında The Holmes Report tarafından 2019 Yılın Ajansı seçilmiştir. Ajans bünyesinde çeşitli uzmanlık alanlarına sahip Grup Cros, Cros Marketing ve Cros Dijital kuruluşları yer almaktadır. İletişim kampanyaları düzenleme, analitik medya araştırmaları, pazarlama iletişimi, görsel içerik, kriz iletişimi ve farmasötik iletişim alanında hizmet sunan kuruluş, AKAR, AKOS, RASO ve Rusya Kurumsal Medya Direktörleri Derneği olan AKMR üyesidir. CROS ayrıca, Silver Archer, SABER Awards EMEA, IABC Gold Quill Awards, IPRA Golden World Awards, PRGN Best Practice Awards, Effie Awards Russia, ICCO Global Awards gibi birçok CROS projesi ulusal ve uluslararası profesyonel ödüllere layık görülmüştür (https://www.cros.ru/ru/, 2021)

EM: EM, 2010 yılında kurulan ve kısa sürede dünya çapında tanınan uluslararası bir halkla ilişkiler ajansıdır. Bu yapısıyla da The Holmes Report'a göre 2020 yılında Avrupa'nın en hızlı büyüyen 10 ajansı arasında yer almıştır. Sermaye piyasası işlemleri, yatırımcı ilişkileri, kriz iletişimi ve itibar yönetimi gibi alanlarda hizmet vermektedir. Ayrıca ESG ve CEO danışmanlığı hizmeti de sunmaktadır. Moskova, Londra, 
New York ve Pekin'de temsilcilikleri bulunmaktadır (https://www.emcomms.com/ru/, 2021)

AGT: AGT İletişim Ajansı, 1996 yılında kurulan tam kapsamlı iletişim hizmetleri sunan 15 uzman şirketi bir araya getiren Rusya'daki bağımsız ve en büyük AGT İletişim Grubu'nun bir parçasıdır. AGT, Afrika, Asya, Avrupa, Okyanusya, Kuzey ve Güney Amerika'da 211 ülkede proje yürütmektedir ve uluslararası meslek derneklerine üyelikleri bulunmaktadır. AGT, dünyanın farklı ülkelerinde kendi ortak ağını geliştirerek global projeler uygulama fırsatına sahiptir. Derecelendirme şirketlerinin dünya sıralamasında yer almaktadır. Hizmet alanları arasında; iletişim araştımaları ve analitiği, kurumsal iletişim, pazarlama iletişimi, finansal ve yatırımc ilişkileri, siyasal iletişim, kriz iletişimi ve sektörler arası iletişim yer almaktadır. Ayrıca kamu sektöründe; Rusya Federasyonu Eğitim ve Bilim Bakanlığı, Rusya Federasyonu Sanayi ve Ticaret Bakanlığı, Rusya Federasyonu Tarım Bakanlığı, Rusya Federasyonu Spor, Turizm ve Gençlik Politikası Bakanlığı, Rusya Federasyonu Ekonomik Kalkınma Bakanlığı ve birçok devlet kurumuna halkla ilişkiler hizmeti sağlamaktadır. Devlet kurumlarının yanısıra otomotiv, eğitim, sağlık hizmetleri, petrol, kimya endüstrisi, gezi ve turizm gibi özel birçok alanda hizmet sunmaktadır (https://www.agtagency.ru/, 2021)

\section{Sivil Toplum Kuruluşlarında Halkla İlişkiler}

Rusya'da sivil toplum kuruluşları hükümet dışı örgütler adıyla anılmaktadır. STK anlayışının temelleri Mihayil Gorbaçov dönemine uzanmaktadır. O dönemde topluma fayda sağlayabilecek devlet dışı kuruluşlar önem taşımaktaydı ve bu kuruluşlar Gorbaçov tarafından desteklenmekteydi. Bu destek 1986 yılından itibaren hızla gelişmiş, bilhassa eğitim alanında faaliyet gösteren kuruluşlar devletin maddi desteğiyle birlikte önemli bir konuma gelmiştir (Aydın ve Aliyeva, 2019, s.180).

Sovyetler Birliği'nin dağılmasının ardından STK'lar Rusya'da refah açığının doldurulmasına yardımcı olmuştur. Rusya yeniden yapılanırken, Amerika ve Avrupanın daha güçlü küresel bağların 
oluşturulmasına ve ulus ötesi aktörlerin güçlenmesine yönelik çağrilar yapıyor olması Rusya'da STK'ların oluşumunda ve güçlenmesinde önemli rol oynamıştır (Dufalla, 2014, s.8-9). Rusyadaki STKları Yurtdışı ve Yurt içi menşeili STKlar olarak ikiye ayırmak mümkündür.

Yurtdışı menşeili STK'lar, sağladıkları maddi destekler sayesinde devletin iç işlerine müdahale etmeye başlamış, Rusya durumu kontrol altına almak zorunda kalmış ve kuvvetli yaptırımlar uygulamaya başlamıştır. Özellikle batılı STK'ların Rusya içindeki faaliyetleri son derece sıkı bir şekilde kontrol altına alınarak Rusya Federasyonu dışından maddi yardım alan kuruluşların "yabancı ajan" olarak kayıt altına alınması yönünde düzenlemeler yapılmış (Doğan, 2015, s.187-188), ardından söz konusu kuruluşlar devletin bizzat kendi denetimi altına alınmıştır. 2005 yılından itibaren yabancı uyruklu kişilerin Rusya'da faaliyet gösteren STK'larda yöneticilik de dahil olmak üzere herhangi bir pozisyonda görev almaları yasaklanmıştır. Burada amaç, yabancı ülkelerin ve dış etkenlerin Rusya'nın devlet işlerine müdahale etmelerinin önüne geçilmesidir. Yabancı STK'lar, yaptıkları maddi yardımlarla fikirlerini ve istedikleri faaliyetleri gerçekleştirme hakkını kendilerinde görmekte idi, 2006 yılı itibarıyla Rusya'da faaliyet gösteren tüm STK'lar devletin sıkı denetimlerine maruz kalmış ve yabancı uyruklu kişilerin çalıştığı, maddi destek aldığı bütün kuruluşların faaliyetlerine ülke üzerindeki dış müdahaleleri engellemek ve halkı terorist ideolojilerin yayılmasından korumak amacıyla son verilmiştir (Aydın ve Aliyeva, 2019, s.180). Bunlar arasında Alman iki kuruluş olan Alman Friedrich-Naumann Vakfı ve Konrad Adenauer Vakfı, Amerikan Open Society Foundation gibi örnekler yer almaktadır. Ayrıca 2017 yılında Putin, Rusya'da faaliyet gösteren yabancı medya kuruluşlarının yabancı ajan olarak değerlendirilmesini öngören yasal değişikliği imzalamış ve böylelikle yurt dışından maddi destek alan yabancı medya kurumlarının yanı sıra bu kurumlarda çalışan gazetecilerin de ajan sayılması meşruiyet kazanmıştır. Rusya Adalet Bakanlığı 10 yayın kuruluşunu yabancı ajan olarak sınıflandırmıştır, bunlar arasında Amerika'nın Sesi, ABD Kongresi tarafından finanse edilen Özgür Avrupa Radyosu ve Currenttime.tv, Azadliq Radiosu, Sibir.Realii, Idel.Realii, Faktograf, Kavkaz.Realii ve Kyrm.Realii bulunmaktadır (https://www.dw.com/tr/ 2021). 
Yurtiçi Menşeili STKlar, siyasi otoritenin desteklerini yanına alan kuruluşlar olarak ele alınmaktadır. Burada devletin görevi olan topluma hizmete katkı sunmaları dolayısıyla önemli görülmektedir.

Rus halkına göre devlet, halkın barınma, eğitim sağllk ve kültüre ulaşmasında nihai garantör konumundadır. Rus halkının çoğunluğu devletin topluma hizmet etmesi gerektiğini düşünmektedir. Bu amaçlara hizmet eden yerli STK'ları teşvik için devlet, her yıl düzenlenen hibe yarışmalarına destek vermekte, vatandaşlara yardım etmek ve yerel sivil toplumu geliştirmek için sosyal yardım hizmetleri sunan kuruluşlara finansman sağlamaktadır (Dufalla, 2014, s.5).

Devletin sıkı denetimi altında olan STK'ların temel amacı, yayımlanmış basın bültenleri, gazete ve elektronik dergiler vasıtasıyla iktidar partisinin propagandasını yapmaktır. Bu işlevinden dolayı da üçüncü sektör olarak adlandırılmaktadır. 2005-2008 yılları arasında Rusya "Renkli Devrim" tehdidine karşı devlete yakın çok sayıda sivil toplum örgütünün kurulmasını talep etmiş ve kuruluş süreçlerini de desteklemiştir. Putin'in bizim çocuklar diye adlandırdığı Faşizm Karşıtı Demokratik Gençlik Hareketi- Nashi; Avrasya Gençlik Ligi; Genç Rusya Hareketi-Rumol; Birleşik Rusya'nın Genç Savunucuları ve Mestneye devletin desteklediği başlıca kuruluşlardır (Doğan, 2015, s.185).

Rusya Federasyonu Maliye Bakanlığı'nın resmi internet sitesinde devletin onayladığı sivil toplum örgütleri yer almaktadır. Söz konusu örgütlere ait bilgiler ve faaliyet alanları şu şekilde açıklanmaktadır (https://minfin.gov.ru/, 2021);

Rusya Federasyonu Kamu Odası: Vatandaşların ihtiyaç ve menfaatlerini gözeten, hak ve özgürlüklerini koruyan bir sivil toplum kuruluşudur. Kamu odasının amacı, vatandaşların devlet yetkilileri ve yerel yönetimlerle iletişimini sağlamak ve bu hususta kamu kontrolünün uygulanmasina yardımci olmaktır (https://www.oprf.ru/, 2021).

\footnotetext{
2 Sivil toplum kuruluşunun Rusça adı Общественная палата Российская Федерации ve ingilizce adı Public Chamber of The Russian Federation olarak dokümanlarda yer almaktadır.
} 
Rusya Kamu Girişimiª Rusya Federasyonu Cumhurbaşkanı'nın 4 Mart 2013 tarihli kararnamesi uyarınca oluşturulmuştur. Oluşum, Rus vatandaşlarının ülkenin sosyo-ekonomik kalkınmasına, eyalet ve belediye yönetiminin iyileştirilmesine yönelik, internet üzerinden düzenlenen oylamalara katılmalarını sağlayan bir sivil toplum örgütüdür. Burada amaç, sivil toplumun gelişmesine ve güçlendirilmesine, vatandaşların devlet işlerinde söz sahibi olabilmesine katkı sağlanmasıdır (https://www.roi.ru/, 2021).

Rusya Oto Sigortacılar Birliği ${ }^{4}$ : Araç sahiplerinin zorunlu hukuki sorumluluk sigortasını yürüten sigortacılar tarafından oluşturulan ve kar amacı gütmeyen kurumsal bir organizasyondur. 48 sigorta şirketinin bir araya gelerek kurduğu bu organizasyon; statüsü yasalarla belirlenen ilk sendika olma özelliği taşımaktadır. Birliğin amacı, araçların teknik denetimini sağlayarak trafikte araçların daha sağlıklı koşullarda kullanılmasını sağlamaktır (https://autoins.ru/, 2021).

Rusya Bölgesel Bankalar Birliği ${ }^{5}$ : Bankalar ile hükümet arasındaki iletişimi sağlayan, bankaların çıkarlarının korunmasına yönelik politikalar belirleyen, ülkenin kredi kuruluşları adına yasal düzenlemeler için altyapı hazırlayan bir kuruluştur. Birliğin amacı, yatırımcıların bankacılık sektörüne duyduğu güveni güçlendirmek, bankacılık hizmetlerinin maliyetini düşürmek ve bankacılık mesleğinin etkinliğini artırmak ve devlet kontrolündeki bankalar dahil olmak üzere tüm kredi kurumları için eşit şartlar sağlayan bir alan oluşturmaktır (https://asros.ru/, 2021).

\footnotetext{
${ }^{3}$ Sivil toplum kuruluşunun Rusça adı Российская общественная инициатива ve Ingilizce adı Russian Public Initiative olarak dokümanlarda yer almaktadır.

${ }^{4}$ Sivil toplum kuruluşunun Ruş̧a adı Российский союз автостраховщиков ve ingilizce adı Russian Union of Auto Insurers olarak dokümanlarda yer almaktadır.

${ }^{5}$ Sivil toplum kuruluşunun Rusça adı Accoциация региональных банков Росcuи ve ingilizce adı Association of Banks of Russia olarak dokümanlarda yer almaktadır.
} 
Moskova Borsasi ${ }^{6}$ : Moskova Borsası, finans piyasalarına güven, verimlilik ve yenilik getirerek, şirketlerin ve vatandaşların finansal hedeflerine ulaşmalarına yardımcı olmayı amaçlayan bir sivil toplum örgütüdür (https://www.moex.com/, 2021).

Maliye Bakanlığı'nın sitesinde onayladığı bu sivil toplum örgütleri, halkla ilişkiler açısından ele alındığında vatandaşların istekleri, beklentileri ve tercihleri doğrultusunda topluma hizmet eden kuruluşlar olması dolayısıyla önem taşımaktadır. Rusya'da STK'ların sıkı denetimi günümüzde de devam etmekte, aktif durumdakiler propaganda amaçlı faaliyet göstermekte ve söz konusu kısıtlı faaliyetler devletin kontrolü altında sürdürülmektedir. Son yıllarda Sivil toplum örgütlerine yönelik yeni bir düzenleme getirilerek sıkı denetimler neticesinde ajan listesinden çıkarılmalarına olanak sağlanmıştır. Denetimlerde kuruluşun son bir yıl içerisinde yabancı ülkelerden finansman almamış olma ve Rusya'daki siyasi eylemlere katılmama şartı aranmaktadır. Bunların yanı sıra devletin güçlü denetim şartları STK'ların ajan statüsünden çıkmalarını zorlaştırmaktadır (https://www.rferl.org/, 2021).

\section{Meslek Örgütlerinde Halkla İlişkiler}

Rusya'da halkla ilişkilerin doğuşuna ve gelişimine bakıldığında çalışmaların Moskova ve St.Petersburg'da yoğunlaştığı, kuruluşların ilk ofislerini bu bölgelerde açtıkları görülmektedir. Moskova'da "Rusya Profesyonel İletişimciler Birliği"7, St. Petersburg'da ise "St.Petersburg Halkla İlişkiler Uzmanları Derneği"8 kurulan ilk profesyonel dernekler olarak anılmaktadır. Bu dernekler, halkla ilişkiler uzmanlarının resmi olarak tanınmasına olanak sağlayan, uygun eğitim fırsatları sağlayan ve halkla ilişkiler uygulayıcıları için yüksek standartlar oluşturan

\footnotetext{
${ }^{6}$ Sivil toplum kuruluşunun Rusça adı Московская биржа ve Ingilizce adı Moscow Exchange olarak dokümanlarda yer almaktadır.

${ }^{7}$ Derneğin Rusça adı Российская ассоциация профессиональных коммуникаторов ve ingilizce adı The Professional Communicators Guild of Russia olarak dokümanlarda yer almaktadır.

${ }^{8}$ Derneğin Rusça adı Cанкт-Петербургская ассоциация специалистов по связям с общественностью ve ingilizce adı St. Petersburg Association of Public Relations Specialists olarak dokümanlarda yer almaktadır.
} 
profesyonel bir iletişim sistemi olarak nitelendirilmektedir. 1993 yllına kadar halkla ilişkiler Rusya'da azımsanamayacak oranda reklamcılıkla ilişkilendirilmektedir. Fakat zamanla halkla ilişkilerin yalnızca reklamdan ibaret olmayan, hızla büyüyen ve gelişen bir alan olduğu anlaşılmaya başlanmış ve bu durum dernekleşme ihtiyacını da beraberinde getirmiştir (Pyhs, 2009, s.26).

Rusya Halkla İlişkiler Derneği ${ }^{9}: 1991$ yılında kurulan "Rusya Halkla İlişkiler Derneği" (PACO), kâr amacı gütmeyen bir kamu kuruluşu olarak kurulmuştur. Dernek, halkla ilişkiler alanının kapsamlı ve sürdürülebilir gelişimi için alt yapının oluşturulması, mesleki etik standartların sektör içinde uygulanması ve halkla ilişkiler alanında lisans ve lisansüstü eğitimin geliştirilmesini amaçlamaktadır. PACO'nun misyonu, halkla ilişkiler sektöründe faaliyet gösteren kurumların, alandaki önemli sorunları çözme çabalarına destek vermektir. PACO, endüstri altyapısının geliştirilmesi, endüstrinin çıkarlarının korunması, etik ve mesleki standartların uygulanması, geliştirilmesi, kontrolünün sağlanması ve halkla ilişkiler için insan kaynaklarının geliştirilmesi ile ilgilenmektedir. PACO, yukarıda değinilen "Silver Archer/ Gümüş Okçu", "Proba Awards/ Proba Ödülleri" gibi tanınmış profesyonel yarışmaların uzun vadeli ortağıdır. PACO'nun üyeleri arasında, halkla ilişkiler ajansları, kendi bünyesinde halkla ilişkiler departmanına sahip kuruluşlar, "halkla ilişkiler" alanında uzmanlık eğitimi veren eğitim kurumları, bireysel üyeler ve halkla ilişkiler alanındaki profesyoneller bulunmaktadır. Bugün PACO 'nun aralarında Rusya'nın önde gelen kurumlarından; mail.ru, AGT, Mikhailov\&Partners, Medialine, Medialogiya, Aeroflot'un da bulunduğu 100'den fazla kurumsal, yaklaşık 200 bireysel üyesi bulunmaktadır. Rusya'nın farklı bölgelerinde şubeleri ve temsilcilikleri bulunmaktadır. Rusya genelinde çeşitli etkinlikler düzenleyen dernek, Ocak 2020'de Moskova'da Halkla İlişkiler Günleri düzenleyerek güncel konularda bligi alışverişlerinin

9 Kısa adı PACO olan derneğin Rusça adı Poсcuйская ассоциация по связям с общественностью ve ingilizce adı Russian Public Relations Association olarak dokümanlarda yer almaktadır. 
yapıldığı sempozyumlara ev sahipliği yapmış ve sorunların tartışıldığ1 platformlar oluşturmuştur (https://www.raso.ru/, 2021).

Rusya İletişim Ajanslarn Birliği ${ }^{10}$ : "Rusya İletişim Ajansları Birliği" (AKAP) ilk olarak 1993 yılında "Rusya Reklam Ajansları Birliği" (PAPA) olarak kurulmuştur. 2000 yılında AKAP olarak yeniden adlandırılan derneğin üyeleri; basın, radyo, televizyon, sinema, internet, ulaşım alanlarında reklam oluşturma, planlama ve satış alanlarında, halkla ilişkiler sektöründe ise satış teşviki, markalaşma, talep oluşturma, sponsorluk alanlarında hizmet vermektedir. 1993 yılında kurulan AKAP'ın 50'nin üzerinde yerel 100'ün üzerinde ulusal üyesi bulunmaktadir.

AKAP'in kurulduğu dönemde, St.Petersburg'daki ajanslar da dernek bünyesine katılarak Rus profesyonel ajanslarının sayılarının artmasında büyük adımlar atılmıştır. Söz konusu ajanslar zamanla ülkedeki önemli kamu kuruluşlarına hizmet etmeye başlamış ve St.Petersburg'da da kamu alanında faaliyet gösteren ajans sayısının artmasıyla birlikte 2006 yılında Rusya İletişim Ajansları Birliği'nin Kuzey Batı ofisinin St.Petersburg'da açılmasına karar verilmiştir. Günümüzde, Kuzey-Batı Temsilciliği AKAP'ın Rusya'daki en büyük temsilciliği olarak faaliyetini sürdürmektedir. Ayrıca AKAP reklam endüstrisindeki en iyileri belirlemek ve sektörü geliştirmek amacıyla Rusya Reklamcılık Akademisi'ni kurmuştur. Düzenlenen ödül törenleriyle alandaki en iyi temsilciler belirlenmekte ve en iyi projeye çeşitli ödüller verilmektedir.

AKAP haritaları, reklam verenlerin sektördeki aktif oyuncuları değerlendirmesi ve iş birliği yapacak bir ajans seçmesi konusunda araç rolü üstlenmektedir. Söz konusu platform şirketleri, yetkinliklerinin, başarılarının, uzmanlıklarının iş özelliklerinin ve yer aldıkları pazarın bir bütün olarak sunulmasına olanak tanımaktadır. Sektör haritaları arasında, ilaç iletişim sektörü haritası, promosyon sektörü haritası, ulusal reklam sektörü haritası platformda yer alan başlıca sektör haritalarıdır (https://www.akarussia.ru/, 2021).

\footnotetext{
${ }^{10}$ Kısa adı AKAP olan derneğin Rusça adı Accoциация коммуникационных агентств Poccuu ve ingilizce adı Association of Communication Agencies of Russia olarak dokümanlarda yer almaktadır.
} 
Halkla İlişkiler Danışmanlık Şirketleri Derneği"1: "Halkla İlişkiler Danışmanlık Şirketleri Derneği" (AKOC), 1999 yılında kurulan Rusya'nın en yetkili iletişim ajanslarını bir araya getiren ve Uluslararası Halkla İlişkiler Danışmanları Birliği (ICCO)'nin Rusya temsilcisi olan resmi bir dernektir. AKOC üyesi olan ajanslar, birlik tarafından kabul edilen etik standartlara uymakla mükelleftir. AKOC'un ana görevleri arasında profesyonel, şeffaf ve etkili halkla ilişkiler hizmetlerinin verilmesi, yüksek etik standartların oluşturulması, halkla ilişkiler eğitimlerinin geliştirilmesi ve dernek üyelerinin kamu yararına temsil edilmesi yer almaktadır. Ticari faaliyetleri için bir potansiyel oluşturmayı, Rusya halkla ilişkiler sektörünü profesyonel anlamda daha yükseğe taşımayı, ticari çıkarları desteklemeyi, Rus halkla ilişkiler ajanslarının uluslararası temaslarını ve ilişkilerini geliştirmeyi misyon edinen dernek, Rusya'da halkla ilişkiler endüstrisinin gelişimi çerçevesinde bir dizi girişim geliştirmekte ve endüstrinin ilkelerini tanımlayabilecek belgeler oluşturmaktadır. AKOC günümüzde, Rusya halkla ilişkiler pazarının önde gelen aktörlerini biraraya getirmekte, sektörün daha da gelişmesi, daha güçlü ve profesyonel duruma getirilmesi adına vektör oluşturmayı hedeflemektedir. AKOC üyeleri, kurumsal iletişim, kriz iletişimi, dış ilişkiler, halkla ilişkiler ve hükümet ilişkileri, finansal iletişim ve yatırımcı ilişkileri, iş ve çalışan iletişimi, dijital iletişim ve siyasal iletişim alanlarında hizmet vermekte ve havacılık endüstrisi, otomotiv endüstrisi, hükümet yapıları ve departmanları, madencilik ve işleme endüstrisi, petrol ve gaz endüstrisi ve eğitim sektöründe faaliyet göstermektedir. Dernek üyelerinin faaliyetleri AKOC tarafından onaylanan Rus denetim firmaları tarafından denetlenmektedir (http://www.akospr.ru/, 2021).

Rusya Halkla İlişkiler Akademisi12: "Rusya Halkla İlişkiler Akademisi" (PAOC), halkla ilişkiler alanında önde gelen profesyonel uzmanlar tarafından kurulmuş olan ve kâr amacı gütmeyen bir ortaklıktır.

11 Kısa adı AKOC olan derneğin Rusça adı Аccoциация компаний-консультантов в области связей с общественностью ve ingilizce adı Russian Public Relations Consultancies Association olarak dokümanlarda yer almaktadır.

${ }^{12}$ Kısa adı PAOC olan derneğin Rusça adı Российская Академия Общественных Связей ve Ingilizce adı Russian Academy of Public Relations olarak dokümanlarda yer almaktadır. 
Rusya'da sivil toplum ve devlet kurumlarının gelişmesinde önemli rol oynayan halkla ilişkiler sektörünün önemini artırmak, yurt içi ve yurt dışında kamu bilincinde, medyada, devlet kurumlarında, iş çevrelerinde sektörün itibarını artırmaya yönelik katkı sunmak, halkla ilişkiler alanında yüksek mesleki ve etik standartlar oluşturmak ve sürdürmek, ülkede halkla ilişkilerin gelişmesi adına kilit öneme sahip bilimsel, eğitici ve öğretici projeler hazırlamak ve desteklemek akademinin temel amaçlarını oluşturmaktadır (http://pracademy.ru/, 2021).

Rus İletişim Derneği ${ }^{13}$ : "Rus İletişim Derneği" (PKA), 2000 yılında, Rusya'da orta ve yüksek öğretim müfredatında iletişim bileşenlerinin geliştirilmesine yönelik çabaların artırılması, yurt içinde ve yurt dışında iletişim eğitimi alanında kazanılan deneyimlerin geliştirilmesi, Rusya'da ve yurtdışında benzer hedefleri ve stratejileri olan kuruluşlarla ortaklık ve işbirliği geliştirilmesi amacıyla kurulmuştur. Rusya'da iletişim araştırma ve teknolojisinin yanı sıra iletişim eğitiminin geliştirilmesi, Rus ve yabancı araştırmacılar ve kurumlar arasındaki disiplinlerarası iletişim alanında uluslararası işbirliğinin teşvik edilmesi derneğin misyonunu oluşturmaktadır. Derneğin amaçları arasında ise, üç ayda bir yayınlanan "The Russian Journal of Communication" dergisinin yayınlanmas1, iletişim bilimleri ve eğitim alanında iki yılda bir kitap yarışması düzenlenmesi, okullarda iletişim alanında konferanslar düzenlenmesi, Rusya eğitim sisteminde iletişimsel eğitim programlarının ve kurslarının geliştirilmesi ve desteklenmesi, bilgi ve yayıncılık faaliyetlerinin yürütülmesi ve bilimsel ve eğitimsel amaçlar için iletişim konularındaki yayınların teşvik edilmesi yer almaktadır. Dernek eğitim alanında ağırlıklı olarak hizmet vermekte ve iletişim araştırmalarının gelişimine katkı sağlamayı amaçlamaktadır. Bu anlamda kültürlerarası iletişim ve dil eğitimi, iletişim terminolojisi, iletişimsel yeterlilik ve etik, kriz iletişimi ve halkla ilişkilerin iletişimsel yönleri derneğin desteklediği araştırma alanları arasında yer almaktadır. İletişim ve halkla ilişkiler alanında uluslararası ortakları bulunmakta ve akademik düzeyde araştırma ve yayımlar yapılmaktadır. Kuzey Amerika Avrasya İletişim

${ }^{13}$ Kısa adı PKA olan derneğin Rusça adı Российская Коммуникативная ассоциация ve ingilizce adı Russian Communication Association olarak dokümanlarda yer almaktadır. 
Derneği, Ulusal İletişim Derneği, Uluslararası İletişim Derneği, Avrupa İletişim Araştırma ve Eğitim Derneği, Kazakistan İletişim Derneği,Uluslararası İletişim Dernekleri Federasyonu ve Medya İzleme ve Halkla İlişkiler Analizi Ajansı, derneğin ortakları arasında yer almaktadır (http://www.russcomm.ru/, 2021).

Rusya İletişim ve Kurumsal Medya Direktörleri Derneğ in$^{14}$ : Rusya İletişim ve Kurumsal Medya Direktörleri Derneği (AKMP), 2004 yılında kurulan iletişim ve medya yöneticilerinin kâr amacı gütmeyen bir sektör derneğidir. Dernek, şirketlerin iç ve dış iletişimleri alanında üyelerinin etkileşimi ve fikir alışverişi sağlanması konusunda etkinlikler düzenlemektedir. AKMP, standartların ve endüstri prosedürlerinin geliştirilmesine katkı sağlayan, eğitim seminerleri düzenleyen, iletişim ve kurumsal medya alanındaki uzmanlara yönelik eğitim programları konusunda eğitim kurumları ile etkileşim sağlayan bir dernek olarak faaliyet göstermektedir. Derneğin hedeflerini, şirket içi ve dışı iletişim, konumlandırma ve tanitım alanlarında bilgi sunulması, pazarlama ve kurumsal kültür alanındaki yöneticiler için ortak bir platform oluşturulması, mesleki bir gündem oluşturularak dernek üyelerinin kurumsal çıkarlarının korunması, standartların ve sektör prosedürlerinin geliştirilmesi, mesleğin prestijinin güçlendirilmesi, şirket içinde değer artışını etkileyen etkili iletişimin oluşturulması, bu bağlamda paydaşlar, medya, personel ve yatırımcılarla iletişimin sağlanması ve iletişim, kurumsal medya ve kurumsal kültür alanında uzmanların ileri düzeyde eğitim almaları adına fırsatların sağlanması oluşturmaktadır. AKMP'nin 50'ye yakın üyesi bulıunmakta ve mevcut üyeler, medya, halkla ilişkiler, finans ve sigorta, telekomünikasyon, ulaşım, medikal, prodüksiyon, danışmanlık ve iletişim alanlarında faaliyet göstermektedir.

Dernek, çeşitli alanlarda yarışma ve ödül törenleri düzenlemektedir. Kurumsal iletişim alanında üst düzey yönetici ve direktörlerin derecelendirildiği "TOP-COMM" ödülleri, "En İyi Kurumsal Medya Yarışması, "Dijital İletişim Ödülleri”, genç iletişimcilere yönelik "MICS-

${ }^{14}$ Kısa adı AKMP olan derneğin Rusça adı Accouиaция директоров по Коммуникациям и корпоративным Meдиa Poccuu ve ingilizce adı The Association of Directors of Communications and Corporate Media of Russia olarak dokümanlarda yer almaktadır. 
Genç Araştırmacılar Yarışması", "En İyi Etkinlik Ajansı Yarışması" her yıl düzenlenen yarışma ve ödül törenleri arasında yer almaktadır (https://corpmedia.ru/, 2021).

\section{Halkla İlişkiler Yarışma ve Ödülleri}

Ülkede sektöre yönelik prestijli yarışmalar düzenlenmektedir. Ulusal ve uluslararası alanda düzenlenen çeşitli yarışmalar neticesinde verilen ödüller şu şekilde sıralanabilmektedir:

Gümü̈ş $\boldsymbol{O} k \boldsymbol{c ̧} \boldsymbol{u}^{15}$ : Rusya'nın en saygın ve prestijli halkla ilişkiler ödüllerinden, Ulusal Halkla İlişkiler Ödülü olan "Gümüş Okçu”, Amerika ve Rusya'nın birçok bölgesinde halkla ilişkiler alanında yarışmalar düzenleyerek ödülleri sahipleriyle buluşturmaktadır. Ödülün temel amacı Rusya'da halkla ilişkilerin anlaşılmasını ve geliştirilmesini sağlamaktır. İlk kurucuları Rusya Halkla İlişkiler Derneği ve Rusya Federasyonu Ticaret ve Sanayi Odası olan Gümüş Okçu, çeşitli şirketlerin temsilcileri, kamu dernekleri, iletişim grupları ve sektör liderlerinden oluşan heyet tarafından yönetilmektedir. Yarışma, iletişim teorisi ve çeşitli format ve türlerde halkla ilişkilerin gelişimi üzerine çalışmaları incelemektedir. Bunlar arasında teorik çalışmalar, ders kitapları, tarihsel araştırmalar, en iyi uygulama örnekleri, halkla ilişkilerin profesyonel alanını popülerleştiren gazetecilik ve sanatsal çalışmalar yer almaktadır (http://www.luchnik.ru/, 2021).

Rusya Sosyal Reklamcılık Yarışması "Yeni Bakış"16: Gençlere belirli bir soruna yönelik tutumlarını ifade etme, sorunu çözmenin yollarını gösterme ve sosyal reklamcılığın gelişimine katkı sağlama fırsatı tanıyan ve yıllık düzenlenen bir gençlik etkinliğidir. Yarışma, 14-30 yaş arası gençlere modern toplumun en önemli sosyal sorunlarına karşı tutumlarını ifade etme fırsatı sunmaktadır. Yarışmanın konuları

\footnotetext{
${ }^{15}$ Ödülün Rusça adı Серебряный лучник ve Ingilizce adı Silver Archer olarak dokümanlarda geçmektedir.

16 Ödülün Rusça adı Bсероссийский конкурс социальной рекламы “Новый взгляд"vе Ingilizce adı Russian Social Advertising Competition "New Look" olarak dokümanlarda geçmektedir.
} 
arasında; ulaşım, kan bağışı, tıbbi bakım, trafik kuralları ve diğer sosyal hususlar oluşturmaktadır (http://www.tvoykonkurs.ru/, 2021).

Proba Ödülleri ${ }^{17}$ : Halkla ilişkiler alanında düzenlenen ve Uluslararası İletişim Ödülü olan "Proba Ödülleri" 2000 yılından itibaren her y1l düzenlenen törenle en iyi iletişim endüstrisi profesyonellerini, ajanslarını ve projelerini ödüllendirmektedir. Cannes Lions, Global SABER Ödülleri ve Gold Quill Ödülleri ile birlikte uluslararası Proba Ödülleri, en yüksek dereceye sahip ("A" sınıfı) Ulusal İletişim Şirketleri Derecelendirmesine dahil edilmiştir. Ödül jürisi, 13 farklı kategoride finalistleri belirlemektedir. Tören her yıl Eylül ayında St.Petersburg'da düzenlenmektedir (https://pr-proba.ru/, 2021).

\section{Sonuç}

1991 yılında SSCB'nin dağılmasının ardından Rusya'da halkla ilişkilere duyulan ihtiyaç, açığa çıkmıştır. Her ne kadar dağılmadan önceki dönemde de bu tip faaliyetler yürütülüyor olsa da dağılmanın ardından gelişmeler hız kazanmıştır. Yeni veya diğer bir anlamıyla Modern Rusya'da halkla ilişkiler ajansları ve dernekler birbiri ardına kurulmuş, devlete ve özel sektöre hizmet vermeye başlamıştır. Başlangıçta Moskova'da yoğunlaşan kuruluşlar zamanla ihtiyacın artmasıyla birlikte başta St.Petersburg olmak üzere ülkenin çeşitli bölgelerinde temsilcilikler açmaya başlamıştır.

Fakat STK'lar için aynı durumdan söz edilememekte, söz konusu kurumlarda devletin yabancılara yönelik güçlü yaptırımları olduğu görülmektedir. Devlet kendi vatandaşları tarafından yürütülen çalışmaları desteklemekte fakat yabancıların kendi kuruluşları söz konusu olduğunda son derece güçlü yaptırımlar uygulamaktadır. Hatta gerek STK'lar ve onların yabancı çalışanları gerekse yabancı gazeteciler "ajan" olarak nitelendirilmekte, bu durum resmi makamlar tarafından onaylanmaktadır. 2015 yılında yürürlüğe giren yasayla STK'ların yabancı ajan statüsünden çıkabilmelerine olanak sağlanmıştır. Ancak

17 Ödülün Rusça adı Ppoбa ve Ingilizce adı Proba Awards olarak dokümanlarda geçmektedir. 
güçlü denetimler ve yerine getirilmesi talep edilen şartların, STK'ların yasa öncesi maruz kaldıkları durumdan farklı olmadığı görülmektedir.

2000'li yıllarda internetin yaygin şekilde kullanılması ve dünya genelinde aktif olarak kullanılan sosyal medya uygulamaları Rusya'da da kamudan özel şirketlere, sivil toplum kuruluşlarından günlük hayata kadar her alanda iletişimi kolaylaştırmıştır. İletişimde en sık başvurulan mecralar olarak günümüzde de hala yaygın olarak kullanılmaktadır. Kamu sektöründe bakanlıklar düzeyinde halkla ilişkiler ajanslarından destek alınmakta ve profesyonel organizasyonlar da yine söz konusu ajanslar tarafından yürütülmektedir. Sayıları gün geçtikçe artan halkla ilişkiler ajansları dünya çapında tanınan büyük şirketlere hizmet vermek için çaba göstermekte, ulusal derneklere üye olmakta ve prestijli ödülleri son derece önemsemektedir. Rusya' da halkla ilişkiler ajansları büyük bir rekabet içinde olmalarının yanı sıra dünya çapındaki sıralamalara girecek kadar halkla ilişkiler ve tanıtım faaliyetlerine önem vermektedir.

Günümüzde Rusya Federasyonu'nun resmi makamları ve bilhassa bakanlıklar profesyonel ajanslardan destek alarak çeşitli konularda farkındalık oluşturmaya çalışmakta, sosyal medya uygulamalarını aktif şekilde kullanmakta ve tanıtıma büyük önem vermektedir. İnternet ve sosyal medyanın tüm dünyadaki iletişim fırsatlarını eşitlemeye çalı̧̧ma işlevi halkı bilgilendirme amaçlı olarak kullanıma da olanak sağlamaktadır. Neredeyse tüm bakanlıkların Twitter, YouTube veya Instagram'da en az bir adet resmi hesabı bulunmakta, ülke tanıtımı adına da bu mecralar aktif bir araç olarak kullanılmaktadır. Dolayısıyla internetin ve sosyal medya uygulamalarının ülkelerin hatta dışarıya en kapalı olanların bile halkla ilişkiler faaliyetlerini yürütmelerindeki işlevi göz ardı edilemez boyutlardadır.

Kamuda bakanlıklardan başkanlık düzeyine, özel sektörde de dünya listelerine girme başarısı gösteren ajanslardan şirketlere kadar halkla ilişkiler çalışmaları yaklaşık 30 yıllık geçmişi olan bir ülke açısından değerlendirildiğinde gayet başarılı bir yükseliş gösterdiği görülmektedir. Fakat, sivil toplum kuruluşları ve yabancı gazetecilere yönelik uygulamalar bu gelişmelerle çelişmektedir. Bu çalışma kapsamında yapılan incelemede Rusya'daki sivil toplum kuruluşlarının siyasi otoriteden bağımsız olmadığı görülmektedir. Aslında halkla ilişkiler çalışmaları sivil toplum kuruluşlarında daha etkin olarak ortaya 
çıkabilir. Dolayısıyla halkla doğrudan temas kurabilecek kâr amacı gütmeyen kuruluşların desteklenmesi halkla ilişkilerin de daha etkili bir şekilde yol almasına vesile olabilir. Hem kamu kurumlarında hem de özel sektör bağlamında uluslararası bir anlamda bile halkla ilişkiler uygulamalarına rastlanırken sivil toplum kuruluşlarında bu anlamda bir gelişmeye rastlanamamıştır. Tabi ki burada birtakım kaygıların da olduğu göz ardı edilmemelidir.

Diğer taraftan, Rusya Federasyonu'nun sadece kendi içine yönelik değil dünyaya kendini anlatabilmek ve tanıtabilmek adına birtakım halkla ilişkiler ajanslarından destek aldığını da söyleyebilmek mümkündür. $\mathrm{Bu}$ anlamda ülkede bulunan ajansların da hem ülke genelinde hem de uluslararası düzeyde çalışmalar yaptığı da gözlemlenmiştir.

Bütün bunlara bakıldığında sonuç olarak gelişme ortamı sağlanılırsa halkla ilişkilerin kamu ve özel sektörde gelişimi daha da hızlanacaktır. Dernekleşme anlamındaki gelişmelere bakıldığında halkla ilişkilerin, meslekleşmesi bağlamında daha da sağlam zemine oturmasına fırsat tanıyacaktır. Sivil toplum kuruluşlarının da hedef kitle bağlamında ulaşabileceği kitleler göz önüne alındığında önemli bir unsur olduğunu söylemek mümkündür. Bu anlamda sivil toplum kuruluşlarının daha fazla bu sürecin içinde olabileceği gerek yasal düzenlemelerin gerekse de toplumsal desteğin sağlanması Rusya'da halkla ilişkilerin gelişmesine katkı sunacaktır. 


\title{
EXTENDED ABSTRACT
}

\section{Status Public Relations in Russia: Document Review on Historical Development and Current Situation}

\author{
Mustafa Akdă̆- Yasemin Cing1 \\ Erciyes University
}

After the collapse of the Soviet Union, a new period was entered in the Russian Federation, and in this new period, the process of adapting to the world, which was not accustomed until then, began. In this process, public relations practices became an issue that New Russia should focus on. Public relations studies, which first started in the public sector, have been applied in the private sector over time. Studies accelerate and public relations agencies, has opened its first offices in Moscow and St. Petersburg, the sector has gradually developed and professional studies have been carried out.

Public relations has become a remarkable field at the academic level, and public relations courses in universities have started to be given with a focus on the sector. The curriculum differs according to the specialization of the faculty, for example; the contents of some university courses in journalism is heavily weighted in some universities, while business and marketing. With the start to be implemented as an active public relations work in Russia in particular has gained popularity for political public relations at the academic level. The aim that will be how to organize political campaigns, public relations and how to make the election campaign in the analysis of practices in this area is to create a system of how to use the technique. In the year 1990 began to open public relations agencies have begun to provide services to the public sector outside of political communication, many government departments were needed to support the agency. In the past this practice even today the foundations were laid in a professional manner and ongoing support of the ministry is an important part of the agency. To create awareness in the society, to ensure the development at grassroots level of social responsibility, to move and take on the task of public relations agencies on various topics, such as to achieve the most healthy 
way exchange of information to maximize public participation through various organizations. Professional support is received from foreign agencies as well as domestic agencies. Social media applications also play an important role at the ministry level.

Public relations practices are also used effectively in the private sector. In recent years, Russian agencies have also found a place among the 250 agencies determined globally by "The Holmes Report", one of the world's leading independent sources. Today, there are many public relations and advertising agencies in Russia. Developing technology, widespread use of the internet by all segments and the importance of social media in terms of promotional activities have offered Russian agencies the opportunity to open up to the world, and in recent years, these agencies have started to offer consultancy services to large companies around the world.

Although public relations was identified with advertising in the period when it was implemented, it was understood that it was a growing and developing field that did not consist of advertisements over time, and as a result of this situation, the need for association arose. The Russian Union of Professional Communicators and the St Petersburg Association of Public Relations Specialists were among the first professional associations to be established. In the following years, new associations were added to the associations and the sector was supported with the competitions and awards. Although public relations agencies in the public and private sectors have achieved various successes by actively operating both in the country and abroad, when nongovernmental organizations are examined, it is seen that the same success cannot be achieved there. NGO's, known as non-governmental organizations, were initially supported by Mikhail Gorbachev, and even at that time, it was aimed to close the welfare gap in Russia after the collapse of the Soviet Union. But, over time, foreign NGO's began to impose strong sanctions, especially on western NGO's, after they found the right to interfere in the internal affairs of the country, to spread their ideas and to carry out the activities they wanted, as a result of the financial support they gave. First, the activities of western-based NGO's were taken under control, and then the practice of registering them as foreign agents was started. After 2005, foreign nationals were prohibited 
from taking any positions, including managerial positions, in NGO's operating in Russia. In 2006, all NGO's operating in Russia were subject to strict controls by the state, and the activities of all organizations where foreign nationals work and receive financial support were terminated in order to prevent foreign interventions in the country and to protect the public from the spread of terrorist ideologies. This practice was also seen in the media sector over time, and in 2017, Putin signed the legal amendment that stipulates that foreign media organizations operating in Russia should be considered as foreign agents, thus, foreign media institutions that receive financial support from abroad, as well as journalists working in these institutions, have gained legitimacy. Thus, NGO's of foreign origin are closely monitored by the state, while domestic NGO's are supported by the state. Some NGO's that have received government approval have been announced on the official website of the Ministry of Finance. The main purpose of NGO's under the strict control of the state is to propagate the ruling party through published press releases, newspapers and electronic journals. Because of this function, it is called the third sector. Between 2005 and 2008, Russia demanded the establishment of many non-governmental organizations close to the state against the threat of the "Color Revolution" and supported the establishment processes. In this context, it is seen that it is not possible to talk about independent NGO's in Russia.

When all these are evaluated, it is understood that a successful rise has been experienced from the point of view of Russia, whose public relations activities have a history of almost 30 years, from agencies to companies that can enter world lists, both at the level of ministry and presidency in the public sector. But strong sanctions against foreign NGO's and foreign journalists contrast with developments in other areas. NGO's cannot act independently from the political authority. Considering that public relations can be implemented more effectively in non-governmental organizations, supporting these institutions in this field develops the idea that public relations will progress more effectively. It is believed that NGO's can use their power effectively with the necessary legal regulations and social support. 


\section{Kaynakça / References}

Akdağ, M. ve Erdem, A. (2009). Halkla ilişkiler tarihi üzerine. M.Işık ve M.Akdağ (Ed.) Dünden bugüne halkla ilişkiler içinde (s.3-51), Konya: Eğitim Kitabevi.

Aydın, K. ve Aliyeva, M. (Kasım 2019). Sivil toplum kuruluşlarının web sitelerinin diyalojik iletişim kullanım düzeylerini belirlemeye yönelik bir analiz (Rusya-Türkiye Karşılaştırması). INIFF E-DERGİ, 4(2),168195.

Bykov, I. A., Igor M. Pobedinskiy, Vera A. Achkasova and Aleksey E. Kuzmin. (2016). Managing Governmental public relations in Russia: Evidences from St. Petersburg. International Review of Management and Marketing, 6(5), 136-142.

Chumikov, A. B. (2013). Governmental PR for state institutions and projects. Moscow: INFRA-M.

Cing1, Y. (2019). Bağımsız Devletler Topluluğu ülkelerine ihracat yapan Kayseri menşeli işletmelerin uluslararası pazarlama iletişimi çalışmaları. (Yayımlanmamış Yüksek Lisans Tezi). Erciyes Üniversitesi, Sosyal Bilimler Enstitüsü, Kayseri.

Doğan, E. (2015). Rusya Federasyonu'nda kamu diplomasisi: Evrim ve kurumlar. Marmara Üniversitesi Siyasal Bilimler Dergisi, Marmara University Journal of Political Science, 3(2) 179-194.

Dufalla, J. (2021, Mart 11). Non-governmental organizations in Russia: Adapting for success. https://www.researchgate.net/publication/332622480_NonGovernmental_Organizations_in_Russia_Adapting_for_Success. adresinden alındi.

Geray, H. (2006). Toplumsal araştırmalarda nicel ve nitel yöntemlere giriş iletişim alanından örneklerle. Ankara: Siyasal.

Goregin, A. and Nikolaev, A.G. (1995). The value of a PR association to Russians. Communication World 12, No.10 (November).

http://imars.ru/. (2021, Nisan 12). O HAC. http://imars.ru/about.php adresinden alındı

http://kremlin.ru/events/president/news/64671. (2020, Aralık 19). http://kremlin.ru: $\quad$ http://kremlin.ru/events/president/news/64671 adresinden alınd 1

http://pracademy.ru/. (2021, Mart 11). ОБ АКАДЕМИИ. http://pracademy.ru/ adresinden alınd 1 
http://russcomm.ru/rca_office/about.shtml. (2021, Ocak 30). adresinden alınd1 http://www.akospr.ru/. (2020, Aralık). http://www.akospr.ru/: http://www.akospr.ru/ adresinden alındı

http://www.akospr.ru/. (2021, Mart 12). Ассоциация компанийконсультантов в области связей с общественностью. $h t t p: / / w w w . a k o s p r . r u /$ adresinden alınd 1

http://www.luchnik.ru/. (2021, Mart 11). Премия. http://www.luchnik.ru/premium/ adresinden alınd 1

http://www.russcomm.ru/. (2021, Mart 11). O PKA. http://www.russcomm.ru/rca_office/index.shtml adresinden alınd1

http://www.tvoykonkurs.ru/. (2021, Mart 11). IX Всероссийский конкурс. http://www.twoykonkurs.ru/ adresinden alınd 1

https://asros.ru/. (2021, Nisan 3). Об Ассоциации. https://asros.rulabout/ adresinden alındı

https://autoins.ru/. (2021, Nisan 2). О Российском Союзе Автостраховщиков. https://autoins.ru/ob-rsa/istoriya-rsal adresinden alındı

https://corpmedia.ru/. (2021, Mart 10). Об ассоциации. https://corpmedia.rulakmr/ob_associacii/ adresinden alındı

https://fmba.gov.ru/. (2021, Mart). Стартовала Всероссийская донорская неделя \#Оставайсядонором. https://fmba.gov.ru/presstsentr/novosti/detail/?ELEMENT_ID=39090Esphrase_id=30759: adresinden alındı

https://minfin.gov.ru/. (2021, Mart 27). https://minfin.gov.ru/ru/om/link/inf_links/nongovorg/: adresinden alındı

https://m-p.ru/. (2021, Nisan 10). О компании. https://mp.ru/company/about_us/adresinden alındı

https://pr-proba.ru/. (2021, Mart 11). О премии. https://pr-proba.ru/ adresinden alınd 1

https://ru.wikipedia.org/wiki/Связи_с_общественностью\#PR_в_России. (2020, Aralık 19). https://ru.wikipedia.org: https://ru.wikipedia.org/wiki/Связи_с_общественностью\#PR_в_Pоссии adresinden alınd 1

https://teacher-of-russia.ru/. (2021, Mart). ВСЕРОССИЙСКОГО КОНКУРСА «УЧИТЕЛЬ ГОДА РОССИИ. https://teacher-of-russia.ru/: https://teacher-of-russia.ru/?page=history 20 adresinden alınd 1 https://www.agt-agency.ru/. (2021, Nisan 9). Компания. adresinden alındı 
https://www.akarussia.ru/. (2020, Aralık). https://www.akarussia.ru/: https://www.akarussia.ru/ adresinden alınd 1

https://www.akarussia.ru/. (2021, Mart 17). Об ассоциации. https://www.akarussia.ru/about adresinden alınd1

https://www.alladvertising.ru. (2021, Mart ). PR агентства в России. https://www.alladvertising.ru: $\quad$ https://www.alladvertising.ru/top/pr/ adresinden alındı

https://www.cros.ru/ru/. (2021, Nisan 11). ИСТОРИЯ И НАГРАДЫ. https://www.cros.ru/ru/: https://www.cros.ru/ru/about/history/ adresinden alındı

https://www.dw.com/tr/rusyada-yabanc\%C4\%B1-gazetecilerajanl\%C4\%B1kla-su\%C3\%A7lanabilecek/a-51508892. https://www.dw.com/tr/rusyada-yabanc\%C4\%B1-gazetecilerajanl\%C4\%B1kla-su\%C3\%A7lanabilecek/a-51508892 adresinden alınd

https://www.em-comms.com/ru/. (2021, Nisan 10). ЕМ - УНИКАЯЬНЫЙ ОПЫТ И ЭКСПЕРТИЗА. https://www.em-comms.com/ru/what-we-do/ adresinden alındı

https://www.moex.com/. (2021, Nisan 3). Московская Биржа. adresinden alınd1

https://www.nytimes.com/2014/09/01/business/media/pr-firm-for-putinsrussia-now-walking-a-fine-line.html. (2021, Mart). adresinden alınd 1

https://www.oecd-ilibrary.org. (2021, Mart). https://www.oecdilibrary.org/education/education-at-a-glance-2013/russian-federation_eag2013-67-en: https://www.oecd-ilibrary.org/education/education-at-a-glance2013/russian-federation_eag-2013-67-en adresinden alındı

https://www.oprf.ru/. (2021, Nisan 1). Структура общественной палаты. adresinden alınd 1

https://www.PRovokemedia.com/. (2021). GLOBAL TOP 250 PR AGENCY RANKING 2020. adresinden alındı

https://www.raso.ru/. (2021, Mart 15). O PACO. https://www.raso.ru/about.php adresinden alınd 1

https://www.raso.ru/. (22021, Ocak). https://www.raso.ru/: https://www.raso.ru/about.php adresinden alindı

https://www.rferl.org/. (2021, Nisan 27). Prominent Russian Rights Group Shuts Down Over 'Foreign Agent' Laws. https://www.google.com/search?q=enes+balErlz=1C1FKPE_trTR929TR929 
$\mathcal{E}$ oq=enes+balEaqs=chrome..69i57j46j018.38366j0j7\&sourceid=chromeE $i e=$ UTF-8 adresinden alınd 1

https://www.rgs.org. Mart).

https://www.rgs.org/CMSPages/GetFile.aspx? nodeguid=b9037cbd-1dca4de2-962e-e62a245d0f22Elang=en-GB adresinden alınd 1

https://www.roi.ru/. (2021, Nisan 3). Что такое «Российская общественная инициатива» (РОИ)? https://www.roi.ru/page/about/ adresinden alınd

Kıral, B. (2020 Sayı:15). Nitel Bir veri analizi yöntemi olarak doküman analizi. Sosyal Bilimler Enstitüsü Dergisi, 8(15), 170-189.

Markov, A. (2014). Public relations for power branches. Moscow: INFRA-M.

Milovidova, M. (2021, Mart 11). What defines Public Relations in Russia?. https://www.researchgate.net/publication/305488593_What_defines_Public_ Relations_in_Russia adresinden alınd.

Pashentsev, E. (2002). Public relations: From business to politics. Moscow:Finpress.

Popov, V. (2002). Dünya ve sivil toplum kuruluşlar. Moskova: Prospekt Yayınevi. Pyhs, L. (2009). A Survey of the current state of Russian public relations. (Yayımlanmamış Yüksek lisans Tezi). Ball State University, Indiana.

Sheresheva, J. and Kopiski, J. (2016). The main trends, challenges and success factors in the Russian hospitality and tourism market. Worldwide Hospitality Tourism Themes, 8(3), 260-272.

Thoburn, H. (2015). Rusya siyasetini anlama kllavuzu. Ankara: SETA Yayınları.

Tsetsura, K. (2003). The Development of public relationsin Russia: A geopolitical approach. E. Sriramesh, \& Dejan, V. içinde, The Global Public Relations Handbook Theory, Research, and Practice (s.303). New Jersey: LAWRENCE ERLBAUM ASSOCIATES, PUBLISHERS.

Voslensky, M. (1991). Nomenklatura. Sovyet Rusya.

Yıldırım, A. and Şimşek, H. (2005). Sosyal Bilimlerde nitel araştırma yöntemleri. Ankara: Seçkin Yayıncllı.

\section{Kaynakça Bilgisi / Citation Information}

Akdağ, M. ve Cıng1, Y. (2021). Rusya'da halkla ilişkiler: Tarihsel gelişimi ve günümüzdeki durumu üzerine doküman incelemesi. OPUSUluslararası Toplum Araştırmaları Dergisi, 18(42), 5803-5839. DOI: 10.26466/opus.939500. 